\title{
Insulin receptor has tyrosine kinase activity toward Shc in rat liver
}

E.V. Páez-Espinosa², C.R.O. Carvalho',

L.A. Velloso ${ }^{1}$ and M.J.A. Saad ${ }^{1}$
Departamentos de ${ }^{1}$ Clínica M édica, Faculdade de Ciências M édicas, and 2Fisiologia e Biofísica, Instituto de Biologia, Universidade Estadual de Campinas, Campinas, SP, Brasil

\section{Correspondence \\ M.J.A. Saad \\ Departamento de Clínica Médica FCM, UNICAMP \\ 13081-970 Campinas, SP \\ Brasil \\ Fax: + 55-19-239-3114 \\ Presented at the XIII Annual Meeting of the Federação de Sociedades de Biologia Experimental, Caxambu, MG, Brasil, August 26-29, 1998.}

Research supported by FAPESP.

Received April 14, 1998 Accepted August 13, 1998

\section{Abstract}

Insulin induces tyrosine phosphorylation of Shc in cell cultures and in insulin-sensitive tissues of the intact rat. However, the ability of insulin receptor (IR) tyrosine kinase to phosphorylate Shc has not been previously demonstrated. In the present study, we investigated insulin-induced IR tyrosine kinase activity towards Shc. Insulin receptor was immunoprecipitated from liver extracts, before and after a very low dose of insulin into the portal vein, and incubated with immunopurified Shc from liver of untreated rats. The kinase assay was performed in vitro in the presence of exogenous ATP and the phosphorylation level was quantified by immunoblotting with antiphosphotyrosine antibody. The results demonstrate that Shc interacted with insulin receptor after infusion of insulin, and, more important, there was insulin receptor kinase activity towards immunopurified Shc. The description of this pathway in animal tissue may have an important role in insulin receptor tyrosine kinase activity toward mitogenic transduction pathways.

Considerable evidence has been accumulated to indicate that activation of tyrosine kinase activity is essential for most intracellular signaling pathways $(1,2)$. Many polypeptides like insulin, IGF-1, PDGF or EGF, acting through the tyrosine kinase capacity of their own receptors, lead to the transfer of phosphate groups of ATP to multiple tyrosine residues on the receptor itself, a mechanism known as autophosphorylation (3). Autophosphorylation of tyrosine-kinase growth factor receptors is required for the full kinase activity toward their own substrates. Interaction of tyrosine phosphorylat-

\section{Key words}

- Tyrosine kinase activity

- Insulin receptor

- Shc

- Insulin action ed receptors with various $\mathrm{SH} 2$ domain-containing effector molecules is responsible for downstream signal transduction leading to biological action (4).

The insulin receptor (IR) tyrosine kinase is activated by two separate events, where three residues, $\mathrm{Tyr}_{1158}, \mathrm{Tyr}_{1162}$ and $\mathrm{Tyr}_{1163}$, located in the so-called regulatory loop, appear to play a central role in this process (5). First, insulin binding partially increases the activity of the insulin receptor tyrosine kinase and stimulates its $B$-subunit autophosphorylation. Second, autophosphorylation of the insulin receptor fully activates the en- 
zyme toward specific intracellular substrate proteins (6). The substrate specificity of the purified insulin receptor tyrosine kinase has been extensively examined in vitro. The receptor prefers substrates in which the tyrosine residue is preceded by an acidic amino acid ( $\mathrm{Y}^{-1}$ or $\mathrm{Y}^{-2}$ position) and is followed by a hydrophobic residue $\left(\mathrm{Y}^{+1}\right)(7,8)$.

These results are consistent with many studies showing that both insulin receptor substrate-1 (IRS-1) and Shc (src homology $2 / \alpha$ collagen related), a ubiquitously expressed intracellular signaling protein, share a related amino-terminal region called Shc and the IRS-1 NPXY-binding (SAIN) domain, also known as PTB/PI domain (9), which displays an amino acid sequence similar to that of the IR specificity, and is able to recognize and bind to the phosphorylated Tyr 972 located within the NPX-Tyr(P) motif of IR (10).

Although the PTB/PI domain of Shc appears to interact with the insulin receptor (11), the tyrosine kinase activity of the insulin receptor towards Shc has not been previously demonstrated. The aim of the present study was to investigate the tyrosine kinase activity of the insulin receptor towards Shc, using partially activated IR and immunopurified Shc from animal tissues.

Six-week-old male Wistar rats (130-150 g) were allowed access to standard rodent chow and water ad libitum. Food was withdrawn $4 \mathrm{~h}$ before the experiments. The rats were anesthetized with sodium thiopental $(25 \mathrm{mg} / \mathrm{kg}$ body weight, ip) and used 10-15 min later, as soon as anesthesia was assured by the loss of foot and corneal reflexes. The abdominal cavity was opened, the portal vein exposed, and $0.5 \mathrm{ml}$ of saline $(0.9 \%$ $\mathrm{NaCl}$ ) with or without $6 \mathrm{pg}$ of insulin was injected. Three min after insulin injection, the liver was removed, minced coarsely, and homogenized immediately in approximately 10 volumes of solubilization buffer A (50 $\mathrm{mM}$ Tris, $\mathrm{pH} 7.4,100 \mathrm{mM}$ sodium pyrophosphate, $100 \mathrm{mM}$ sodium fluoride, $10 \mathrm{mM}$
EDTA, $10 \mathrm{mM}$ sodium vanadate, $2 \mathrm{mM}$ PMSF, $0.1 \mathrm{mg} / \mathrm{ml}$ aprotinin, and $1 \%$ Triton$\mathrm{X} 100$ ), at $4^{\circ} \mathrm{C}$ with a Polytron PTA $20 \mathrm{~S}$ generator (Brinkmann Instruments model PT 10/35; Westbury, NY) operated at maximum speed (setting 10) for $30 \mathrm{~s}$. After extraction the samples were centrifuged at $12,000 \mathrm{rpm}$ at $4^{\circ} \mathrm{C}$ in a Beckman $70.1 \mathrm{Ti}$ rotor (Beckman, Palo Alto, CA, USA) for 30 min to remove insoluble material, and the resulting supernatant was used for immunoprecipitation with anti-insulin receptor or anti-Shc antibodies. The immune complexes were precipitated with protein A Sepharose $6 \mathrm{MB}$. After immunoprecipitation Shc protein was subjected to immunopurification techniques by washing three times with a buffer containing $300 \mathrm{mM} \mathrm{NaCl}, 0.03 \%$ (v/ v) Tween $20,2 \mathrm{mM}$ PMSF and $0.1 \mathrm{mg} / \mathrm{ml}$ aprotinin. The complexes were then resuspended in $30 \mu \mathrm{l}$ of $0.2 \mathrm{M} \mathrm{Na}_{2} \mathrm{CO}_{3}, \mathrm{pH} 11$, and incubated in $20 \mu \mathrm{l}$ of a buffer containing $1 \mathrm{M}$ Tris, pH 6.8, 0.02\% (v/v) Tween 20, 3 mM PMSF and $0.1 \mathrm{mg} / \mathrm{ml}$ aprotinin. The protein kinase activity was measured by adding immunoprecipitated IR and immunopurified Shc in $100 \mu$ of buffer containing $50 \mathrm{mM}$ Tris, $\mathrm{pH}$ 7.4, $0.2 \mathrm{mM}$ sodium vanadate, $0.1 \%$ Triton-X 100, $3 \mathrm{mM} \mathrm{MnCl}{ }_{2}$ with or without $15 \mu \mathrm{M}$ ATP for $30 \mathrm{~min}$ at room temperature (12). The complexes were washed once with the same kinase buffer and then resuspended in $20 \mu \mathrm{l}$ of Laemmli sample buffer with 200 mM DTT (13), and subsequently separated by $8 \%$ SDS-PAGE. Proteins in the gel were electrophoretically transferred to nitrocellulose in a Bio-Rad miniature transfer apparatus (Mini-Protean) as described by Towbin et al. (14). The incorporation of phosphate into insulin receptor and Shc was visualized by autoradiography of anti-phosphotyrosine immunoblots. The prestained molecular weight standards used were myosin (194 $\mathrm{kDa}), \beta$-galactosidase (116 kDa), bovine serum albumin $(85 \mathrm{kDa})$, and ovalbumin (49 $\mathrm{kDa})$.

When Shc immunopurified from 4-h 


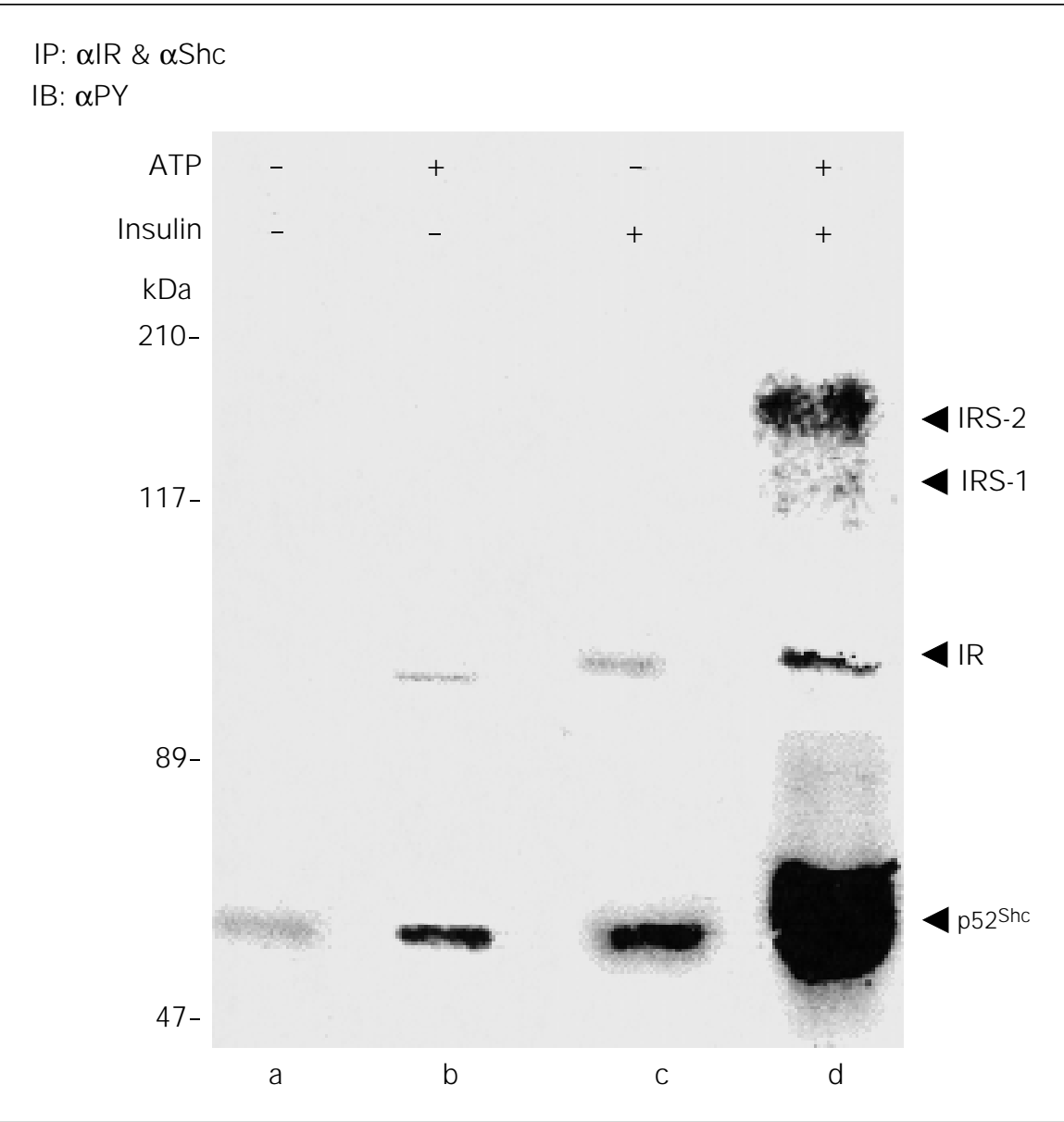

Figure 1 - IR tyrosine kinase activity measured by autophosphorylation with immunopurified complex. The rats were anesthetized and the abdominal wall was incised to expose the viscera. Saline or $6 \mathrm{pg}$ of insulin (as indicated in the figure) was administered as a bolus injection into the portal vein of the rat and the liver was excised $3 \mathrm{~min}$ (the intermediate between maximal times of IR and Shc tyrosine phosphorylation in liver) after insulin injection to stimulate partial IR autophosphorylation. IR was then immunoprecipitated and Shc was immunopurified as described in Methods, and then allowed to react in vitro in the presence of exogenous ATP (lane d). Tyrosine phosphorylation was measured by immunoblotting the ATP-stimulated pellet with an antiphosphotyrosine antibody. Control conditions are shown in lanes $a$ and $b$. In lane $a$, the liver extract was not exposed to insulin or ATP. In lane b, the liver extract was not exposed to insulin, but ATP was added to the in vitro autophosphorylation reaction. In lane $c$, insulin (6 pg) was infused into the portal vein and the liver extracted after $3 \mathrm{~min}$, but no exogenous ATP was added during the in vitro phosphorylation step. In lane d, insulin was infused and ATP was added to the in vitro phosphorylation reaction. This experiment was performed 5 times with closely similar results. fasted non-insulin stimulated rat liver were added to immunoprecipitated IR complexes from liver of rats exposed to $6 \mathrm{pg}$ of insulin stimulus, a lower basal level of $\mathrm{p} 52^{\text {Shc }}$ phosphorylation independent of the ATP in vitro assay was observed (Figure 1, lane a). After 3 min, a time between maximal IR and Shc phosphorylation levels in liver after insulin infusion in vivo, a weak IR tyrosyl phosphorylation was also observed, with little increase in the intensity of the lower band ( $~ 55$ $\mathrm{kDa}$ ) (Figure 1, lane c). After in vitro cold ATP addition, the IR and $\mathrm{p} 52^{\text {Shc }}$ bands became stronger than their respective non-ATPstimulated bands (Figure 1, lanes b and d), but IR remained phosphorylated to a lesser extent than Shc. Two upper weak bands also appeared. It was previously demonstrated that these bands are IRS-1 and IRS-2 (15).
Over the past few years, considerable progress has been made in elucidating the signaling pathways downstream from tyrosine phosphorylation. The data of the present study show an already known pattern of insulin receptor tyrosine phosphorylation occurring during the early intracellular steps of insulin signaling in rat liver, which could be crucial for the insight into the molecular basis for insulin receptor tyrosine kinase mitogenic transduction pathways.

The insulin-stimulated phosphorylation of Shc occurs at physiological post-prandial insulin levels as shown in Figure 1, and leads to association with the Grb2-SOS complex to activate p21 ras $(16,17)$, which activates mitogenesis by activating the mitogen-activated protein kinase (18). Therefore, a key to understanding the mechanism of how acti- 
vated insulin receptors increase the amount of $\mathrm{p} 21^{\text {ras }}$-GTP lies in the clarification of the mechanism of linkage between insulin receptor and Shc.

Shc can interact with tyrosine-phosphorylated growth factor receptors in three different ways, either through its $\mathrm{SH} 2$ domain or its amino-terminal domain, or both (1618). Increasing evidence indicates that the amino-terminal domain of Shc is responsible for the binding to phosphotyrosine residues of the growth factor receptors. Such evidence was based on cell culture in vitro assays and also on the sensitive two-hybrid assay of protein-protein interaction which demonstrated that Shc interacts directly with IR $(19,20)$.

Unlike EGF and PDGF receptors, coimmunoprecipitation studies have not shown interaction between Shc and the IR in vivo. It seems that the interaction of Shc with the IR, in spite of being of sufficient affinity to localize these molecules adjacent to the IR kinase to promote phosphorylation, may be of a low enough affinity to allow these molecules to rapidly dissociate from the activated receptor following phosphorylation, causing a reduced binding affinity of Shc to the IR, and impairing the analysis of the association of these two proteins (18).

Our results show that Shc interacts with the insulin receptor after insulin stimulation in rat liver. Furthermore, there is a kinase activity of the insulin receptor towards immunopurified Shc. We have previously demonstrated that insulin induces Shc tyrosine phosphorylation in rat tissues, and a kinase activity of the insulin receptor towards Shc was also suggested (15). The results presented here clearly demonstrate that the insulin receptor is able to induce tyrosine phosphorylation of immunopurified Shc.

It is interesting to note that besides the insulin receptor and Shc, that was added to the reaction, two other bands appeared and became phosphorylated after the addition of ATP. By immunoblotting with specific antibodies it was previously demonstrated that these bands correspond to IRS-1 and IRS-2 which probably were bound to the insulin receptor after insulin stimulation (15).

In summary, we have demonstrated that, after an infusion of very low doses of insulin in the intact rat, it is possible to demonstrate that the insulin receptor has tyrosine kinase activity toward immunopurified Shc.

\section{References}

1. White MF, Shoelson SE, Keutmann H \& Kahn CR (1988). A cascate of tyrosine autophosphorylation in the ß-subunit activates the insulin receptor. J ournal of Biological Chemistry, 263: 2969-2980.

2. Wilden PA, Siddle $K$, Haring $E$, Backer J M, White MF \& Kahn CR (1992). The role of insulin receptor kinase domain autophosphorylation in receptor-mediated activities: analysis with insulin and anti-receptor antibodies. J ournal of Biological Chemistry, 267: 13719-13727.

3. Ullrich A \& Schlessinger J (1990). Signal transduction by receptors with tyrosine kinase activity. Cell, 61: 203-212.

4. Pawson T\& Gish GD (1992). SH2 and SH3 domains: from structure to function. Cell, 71: 359-362.

5. Wilden $P A$, Kahn $C R$, Siddle $K \&$ White MF (1992). Insulin receptor kinase domain autophosphorylation regulates receptor enzymatic functions. J ournal of Biological Chemistry, 267: 16660-16668.

6. Carvalho CRO, Brenelli SL, Silva AC, Nunes ALB, Velloso LA \& Saad MJA (1996). Effect of aging on insulin receptor, insulin receptor substrate-1, and phosphatidylinositol 3-kinase in liver and muscle of rats. Endocrinology, 137: 151-159.

7. Wilden $P A$, Backer J M, Kahn CR, Cahill DA, Schoeder GJ \& White MF (1990). The insulin receptor with phenylalanine replacing tyrosine-1146 provides evidence for separate signals regulating cellular metabolism and growth. Proceedings of the National Academy of Sciences, USA, 87: 3358-3362.

8. Hubbard SR, Wei L, Ellis $L \&$ Hendriksoon WA (1994). Crystal structure of the tyrosine kinase domain of the human insu- lin receptor. Nature, 372: 746-754.

9. Shoelson SE, Chatterjee $S$, Chaudhuri M $\&$ White MF (1992). YMXM motifs of IRS1 define substrate specificity of the insulin receptor kinase. Proceedings of the National Academy of Sciences, USA, 89: 2027-2031.

10. van der Geer P, Wiley S, Lai VKM, Olivier J P, Gish GD, Stephens R, Kaplan D, Shoelson S \& Pawson T (1995). A conserved amino-terminal Shc domain binds to phosphotyrosine motifs in activated receptors and phosphopeptides. Current Biology, 5: 404-412.

11. Kavanaugh WM, Turck CW \& Williams LT (1995). PTB domain binding to signaling proteins through a sequence motif containing phosphotyrosine. Science, 268: 1177-1179.

12. Saad MJ A, Carvalho CRO, Thirone ACP \& 
Velloso LA (1996). Insulin induces tyrosine phosphorylation of J AK2 in insulin-sensitive tissues of the intact rat. J ournal of Biological Chemistry, 271: 22100-22104.

13. Laemmli UK (1970). Cleavage of structural proteins during the assembly of the head of bacteriophage T4. Nature, 227: 680-685.

14. Towbin H, Staehlin J \& Gordon J (1979). Electrophoretic transfer of proteins from polyacrylamide gels to nitrocellulose sheets. Procedure and some applications. Proceedings of the National Academy of Sciences, USA, 76: 4350-4354.

15. Páez-Espinosa V, Carvalho CRO, Alvarez $F$, J aneri L, Velloso L, Boschero $C \&$ Saad MJA (1998). Insulin induces tyrosine phosphorylation of Shc and Shc/Grb2 association in insulin-sensitive tissues of the intact rat. Endocrine, 8: 193-200.

16. Rozakis-Adcock M, McGlade J , M bamalu G, Pelicci G, Daly R, Thomas S, Brugge J , Pelicci PG, Schlessinger J \& Bar-Sagi D (1993). Association of the Shc and Grb2/ Sem 5 SH2-containing proteins is implicated in activation of the Ras pathway by tyrosine kinases. Nature, 360: 689-692.

17. Sasaoka T, Langlois WJ, Leitner J W, Draznin B \& Olefsky J M (1994). The signalling pathway coupling epidermal growth factor receptors to activation of p21ras. J ournal of Biological Chemistry, 269: 32621-32625.

18. Pronk GJ , De Vries-Smith AMM, Buday L,
Downward J , Masse J A, Medema RH \& Bos J L (1994). Involvement of Shc in insulin- and epidermal growth factor-induced activation of $\mathrm{p} 21^{\text {ras }}$. Molecular and Cellular Biology, 14: 1575-1581.

19. Pringent SA, Pillay TS, Ravichandran KS \& Gullick WJ (1995). Binding of Shc to the NPXY motif is mediated by its $\mathrm{N}$-terminal domain. J ournal of Biological Chemistry, 270: 22097-22100.

20. Gustafson TA, He W, Craparo A, Schaub CD \& O'Neill T (1995). Phosphotyrosinedependent interaction of Shc and insulin receptor substrate 1 with the NPEY motif of the insulin receptor via a novel non$\mathrm{SH} 2$ domain. Molecular and Cellular Biology, 15: 2500-2508. 


\section{AN EVOLUTION IN BIOMEDICAL}

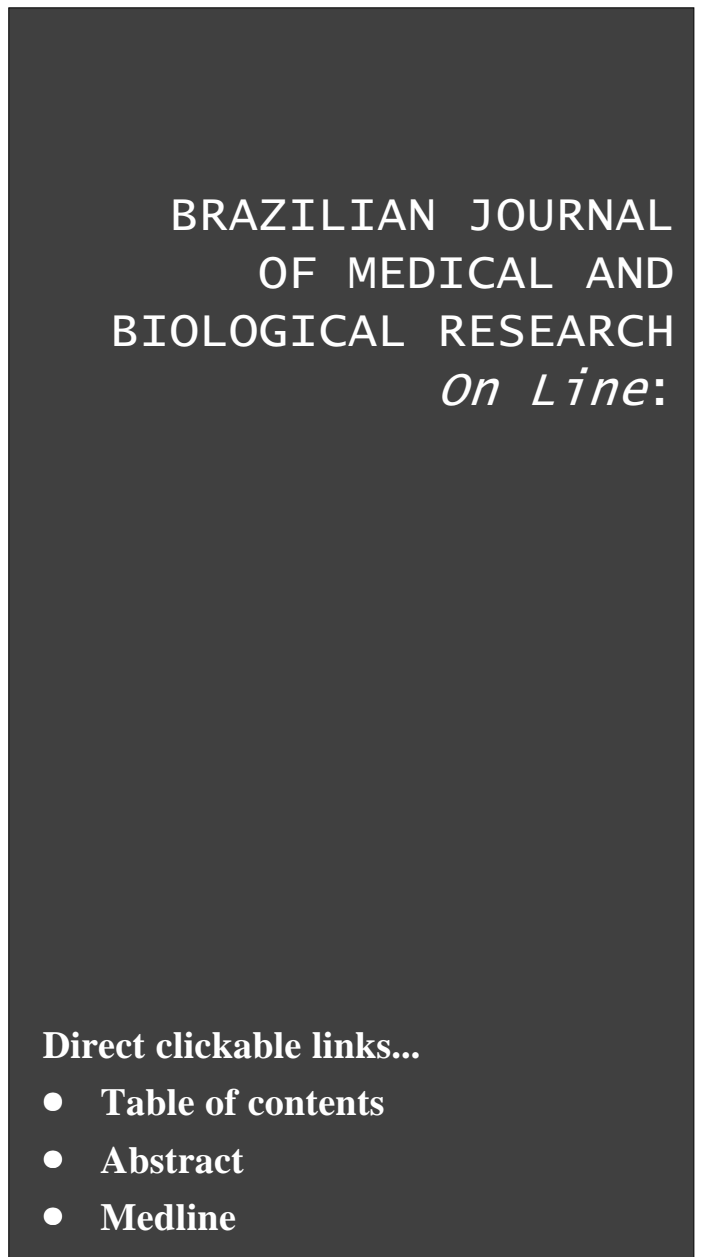

Searchable....

- Search by Keywords, Author, Subject

View or print...

- Abstract

- Full text

- PDF (Adobe Acrobat) files

\section{COMMUNICATION}

\section{http://www.scielo.br/}

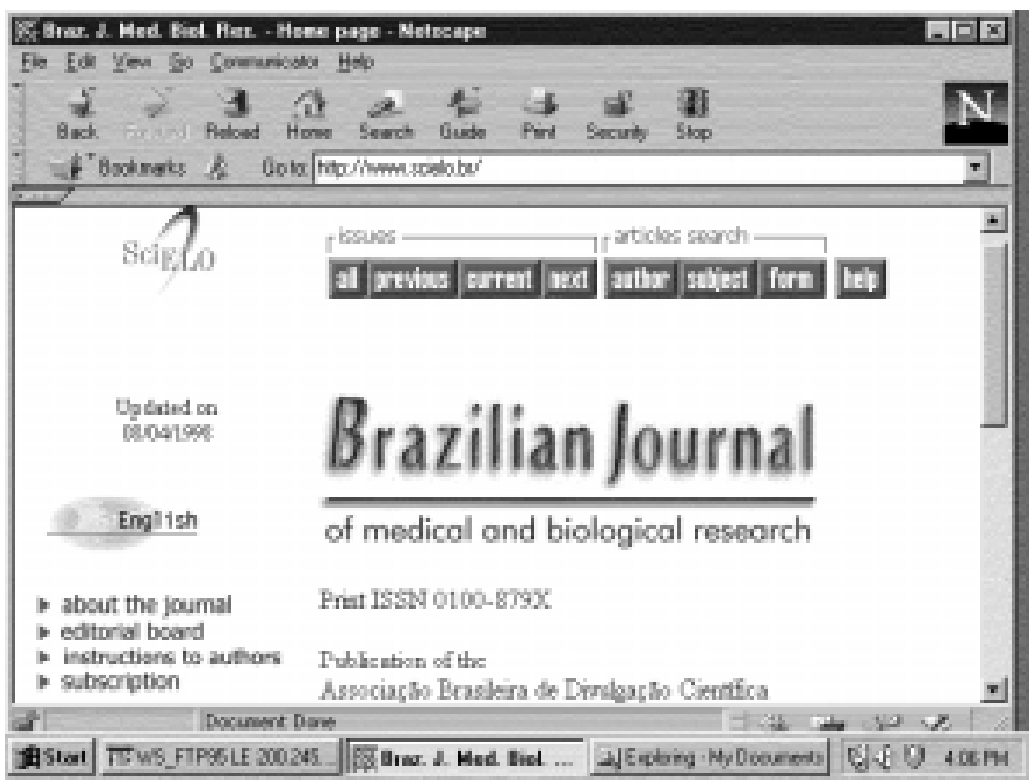

The internet version of the Brazilian Journal of Medical and Biological Research is "published" on the effective date of the print version and permits access to all of 1997 and 1998 and future issues as they are published.

From your desktop, a simple mouse click takes you directly to your areas of interest, or you may browse all on-line issues.

Questions? Please contact our Office

Brazilian Journal of Medical and Biological Research Av. Bandeirantes 3.900

14049-900 Ribeirão Preto, SP, Brazil

Tel Fax(55) 16-633-3825

email: bjournal@fmrp.usp.br 